\title{
Fixed-term and temporary: Teaching Fellows, tactics and the negotiation of contingent labour in the UK Higher Education system
}

Abstract. This paper autobiographically considers the role of teaching-only staff as a contingent labour force in the contemporary Higher Education system in the UK. The aims of this paper are twofold. First, whilst much attention has been paid to the role of the research fellow, there has been less consideration, in the UK context, of the Teaching Fellow as an alternate form of postdoctoral experience. Accordingly, this paper gives voice to the Teaching Fellow - a member of academic staff who is not allocated writing and research time as part of their contract - whose views are often marginalised in on-going debates concerning the plays of power in the neo-liberalised academy. Second, the paper raises these voices to bring into consciousness the impacts of Teaching Fellow experience for the Fellow themselves and the faculties they work in. It is argued that Teaching Fellows face challenging circumstances in view of their onwards career trajectories in the academy. Accordingly, this paper considers the ways in which Fellows, through tactics of place making, presence and visibility, and collaboration, negotiate the challenging structural and institutional conditions that underscore their contracts. It is contended that exploring the teaching-only workforce is vital for critically assessing the workings of the contemporary academy and questioning the unequal power relations that underscore work places in a culture where contingent labour is expanding; becoming less of a fixed-term and temporary feature of the university system, but rather a stable and enduring one.

Keywords: contingent labour, Higher Education, fixed-term, temporary, teaching 


\section{A reflection}

$\mathrm{I}^{1}$ began writing this paper a year ago, from an office tucked away at the end of a corridor, in a Geography department in northern England. I was surrounded by boxes that contained my academic books, box files of papers, teaching folders, several mugs, tea bags and a cafetière all staples of an academic career - all contents of an office I would soon be vacating. I was at the end of my first postdoctoral position. I'd felt lucky ${ }^{2}$ when I had arrived to a fixed-term Teaching Fellow post at a leading UK, Russell Group university. It was a challenging climate and I had secured a job, no matter how short the contract. It was a first step on the academic ladder.

Such posts, fixed-term and temporary (that is, of a specified, short-term duration), are a current feature of the contemporary Higher Education system in the UK, which is increasingly shaped by neoliberal and corporate processes (see Castree and Sparke, 2000) that drive a "casualizaton of academic labour" (Shelton et al, 2001, page 434) to meet the necessary, periodic demands of institutions for teaching and research requirements. Around July or August of each year (before the new academic year begins) or at Christmas time (before the Spring semester starts), a handful of posts, so called 'Teaching Fellowships', emerge on academic job websites in the UK. Such posts are normally temporary, fixed-term appointments designed to cover short-term teaching requirements within a department. Teaching staff usually make a 'significant contribution' (as my job advert stated) to the departmental curriculum, teaching across a range of modules, from first to final year undergraduates and Masters students, in a variety of styles (from lectures, seminars, and tutorials, to supervision sessions for dissertations), across a number of settings (from the

\footnotetext{
1 'I' refers to the first named author on the paper.

2 See Purcell (2007 page 127), who argues that temporary staff often feel grateful for jobs they rightfully deserve.
} 
office, the lecture theatre to the fieldclass site). Teaching Fellows also often have personal tutees (and so, pastoral responsibilities) and are involved in teaching-related administrative tasks (from writing handbooks, managing online module resources, and marking, to convening modules, and so on).

When I took up my post as a Teaching Fellow I was given an office normally occupied by the member of staff whose teaching and teaching-related responsibilities I would be covering. I became quite attached to 'my' office. It was where I had held my first tutorial, had my first dissertation meeting, wrote my first lectures. In short, it was a space in which I'd spent the majority of the last year of my life. I'd made it my own. I had become attached to it. And as I faced leaving, I felt sad. Moreover, as a geographer whose area of study concerns processes of place-making and mobility, I felt the changes I was experiencing acutely. I was aware of the ways in which place-making, mobility, materiality and routine were working to connect and then disconnect me from where I was. At the time, I felt compelled to write about it. Producing a paper was an act of communicating the sense of loss, uprooting and uncertainty I was feeling as I moved on.

\section{A relocation}

In order to pursue my career, I finished my post and left the office at the end of the corridor and moved 200 miles west. I rented a new flat. I walked around a new town, trying to familiarise myself with the streets and the shops. I took up a new position in a new institution. I was given a new office. The aforementioned items, which materialised 'my place' elsewhere, were quickly unpacked, placed on shelves, in filing cabinets, on my desk, and pinned to the walls. The teaching term began. I was busy. I was writing new lectures, 
preparing for seminars and holding tutorials. I was working with new faces and drinking coffee with different friends. Due to the intensive schedule of teaching, writing took a backseat as I sought to root myself somewhere else (that somewhere else being the unfamiliar here). I often thought about that other place and when I had a moment, I thought about this paper. It was a product of a particular moment in time and a particular socio-spatial situation. It was nostalgic and self reflective. But I knew that underpinning the feelings I communicated were the relations of power I was embroiled with - the neo-liberalised academy of which I was a part - that moved me from one place to another as I engaged in a capital/labour exchange as I sought to progress my career. I was unsure how to move forwards with it. I sat on the paper for a while (as the saying goes).

Some six months later I met Jen. This is what happened next.

\section{A coffee}

Jen was a Teaching Fellow in the institution I had just joined. We hit it off. We had a shared experience of the fixed-term, temporary employment market that bonded us. We were both academics seeking to find a place for ourselves in a testing time of funding cuts, budget squeezes and short-term contracts. We discussed our roles in depth; how we'd come to be where we were.

A Teaching Fellowship seemed the obvious step in my career after I completed my $\mathrm{PhD}$ in the summer of 2011. I had applied for a Postdoctoral Research Fellowship (PDF) towards the end of my doctoral research and had been unsuccessful. PDF funding was (and still is) evaporating with broader economic uncertainty, governmental change and alterations to the prerogatives of funding councils. I had taught seminars during my $\mathrm{PhD}$ and I enjoyed 
the experience. Teaching seemed to be a natural pathway to follow. I saw a post advertised. It was for five months, September to January, to cover one semester of teaching. It was not an ideal contract to apply for, especially given the extent of the move I'd have to make if successful (from the South to the North). I'd also need to start applying for the next job as soon as I arrived (I'd be contemplating my onwards mobility even as I was moving). Also, as the contract expired in January, I would find myself out of work at a time of the year where there would potentially be fewer posts to apply for. Furthermore, it would be my first teaching post. It was likely to be hectic and would no doubt detract from efforts to publish from my $\mathrm{PhD}$ (publications being the route to more secure employment). It was risky to say the least, but I took a punt. I applied. I got the job.

Jen spoke of how she was appointed to her post.

I'd had a busy autumn semester of tutorial teaching, guest lecturing and completing the first draft of my PhD. A six-month (January to June) post came up in the department I had been studying in, to cover the teaching of an outgoing Professor. I had applied for Teaching Fellowships elsewhere, but the absence of a completed thesis seemed to be a contributing factor to my lack of success in shortlisting. In the department they knew me and that I was in a position to take on this role. I was confident in my abilities to teach in a department I had spent my whole academic career in. I knew the other staff well, had taught on some of the modules and undertaken them myself as both an undergraduate and a Master's student. However, the spring semester was going to be a tough one. The position required team teaching on a variety of different modules and, although I was excited by the prospect, previously un-encountered responsibilities such as marking and supervising dissertations would be required. Aside from this, it was crucial that I complete my thesis as soon as possible in order to make myself a competitive option for any other posts beginning in the 
next academic year. I also had a number of publications at various stages that I needed to work on. The latter two things would have to run parallel with the contract, taking a back seat to the job I was being paid to do. But, if I wanted to compete in the job market, especially for Lectureship roles in the future, I needed more teaching experience. Whilst I had undertaken a variety of roles during my $P h D$, my $C V$ was missing the quantity and continuity that this role would offer. I applied for the position. I was appointed. I prepared myselffor a hard semester.

Jen's experience was different from my own. She'd studied at this institution as an undergraduate and postgraduate and now she was a member of staff too. But unlike me, she hadn't moved. She hadn't uprooted. She'd made a place and she'd stayed. She was temporary in view of her employment, but she was fixed in the department. She had been there for seven years. Her experiences of temporary, fixed-term working were shaped by immobility. There was change through time, of course; her experience was not a static one. Yet whilst she had in some senses moved (her mobility a situational shift from student to student/staff) her position was still uncertain. The way she dealt with her post was geographically and spatially distinct from my own narrative but was likewise shaped by the contingent nature of her employment driven by broader structural and economic processes.

We discussed how these processes had shaped our academic pathways and the tactics we employed as we tried to make a place for ourselves when living through these particular temporary contracts. Our research interests complemented one another in thinking through these experiences. Whilst I was concerned with place and mobility, Jen's research focused on senses of home, belonging and unequal power relations. We became interested in critically unpacking our experiences as temporary and fixed-term additions to the academy. We wanted to explore how this uncertain position was negotiated through the power relations 
underscoring our situations: the fixed-term nature of our roles, decided upon by institutional budgets and buy-outs, and the long-standing academic view that teaching was somehow less important than research (see Hammett, 2010, page 447). How did this context shape the ways in which the fixed-term, temporary nature of our employment was tackled so that we could work towards productive outcomes for our future careers? And how was all of this specific in view of the type of post we held: as UK Teaching Fellows (rather than Research Fellows)?

We had a coffee. (We had lots of coffee). We talked. (We talked a lot). I began to see a productive way forward with my paper. It became our paper.

\section{A collaboration}

In this paper, we draw autobiographically and reflexively on our varying experiences as Teaching Fellows in the UK academy. We do so in order to critically examine the power relations in our own working environments and attempts to negotiate such power relations to achieve productive outcomes in the face of challenging employment conditions. Whilst discussions of teaching or teaching staff are present in Higher Education and geographyspecific literature (see Baulder, 2006; Dowling, 2008; Heyman, 2007; Purcell, 2007) it remains the case that critical accounts of teaching-only staff experiences are fewer than those of research fellows or permanent faculty members. There has also been less attention in geography, at least, to the UK Teaching Fellow as a particular member of the academic workforce (see Purcell 2007 for the US context ${ }^{3}$ ). Teaching Fellows, in general, are often less likely to have the opportunity to add to current debates on the shape of the academic labour

\footnotetext{
${ }^{3}$ There is significant work that considers non-tenured staff in the US and their teaching-intensive positions (see Purcell, 2007). This paper adds to these interventions through considering the distinctive shape of such roles in the UK context, whereby different economic, political and institutional policies apply.
} 
market, because, as Purcell (2007) notes, they are not allocated research or writing time as part of their contracts. However, it is imperative that they (we) are included in these debates. Teaching Fellows have a particular working experience which offers a new, often marginalised perspective to current debates about postdoctoral experience, the neoliberal academy and contingent working; and how such conditions are tactically negotiated.

Accordingly, in this paper we consider how UK Teaching Fellows such as ourselves, tactically manage the fixed-term and temporary nature of our employment; how they (we) grapple with institutional and broader structural constraints to work towards enabling outcomes from contingent conditions. In what follows, we take a similar approach to Hammett (2012), Purcell (2007) and Rossi (2007), critically and reflexively teasing out the negotiations we have practised through the similarities and differences in our experiences. This takes the form of personal experience narratives (see Denzin 1989) whereby we "take on ... dual identities" of both researcher and 'insider' to tell autobiographical stories about our daily experiences (Ellis and Bochner 2000, 740). Moreover, most existing literature stresses the unequal power relations between permanent and non-permanent staff (Purcell, 2007) and issues concerning feelings of belonging and alienation as scholars tread the line as insider and outsider simultaneously (Hammett, 2012). Less is said of the ways postdoctoral, fixed-term staff creatively and tactically negotiate structural and institutional challenges through everyday employment practices. Arguably it is imperative to draw out and examine such experiences, so that we better understand and can perhaps also critique (see Purcell, 2007) our working lifeworlds.

To do so, we begin by reviewing the geographical interventions that have examined the structural and institutional shape of contingent and academic labour markets and the key conclusions drawn from this work. We then go on to discuss the possibilities of tactics for 
negotiating the plays of power involved in the UK Higher Education system for temporary, teaching-only staff. We then turn to the ways in which fellows tactically negotiate the constraining structural and institutional factors that underpin their (our) roles. We contend that these tactics are inherently spatial. Here we stress that place-making, presence and visibility, and collaboration are methods through which we were able to subvert the limitations placed upon us: our contracts, the perceived role of teaching-only staff, and the broader economic climate in the academy. We conclude by arguing that Teaching Fellows such as us, whose experiences hold both similarities and differences, can engage creatively in the neoliberal academy.

\section{Teaching Fellows and the Contingent Workforce}

Teaching Fellows working in the UK academic labour market are just one segment of a wider workforce whose experiences are increasingly shaped by the post-Fordist, globalising, neoliberal economies we find ourselves living in (see Amin, 1994; Dicken, 2003). Consequently, the how, where, when, and by whom work is organised in contemporary society is changing. These structural changes apparent since the 1980s have, in general, facilitated the fragmentation of workers across space and the development of shorter-term employment contracts leading to the emergence of a 'contingent' workforce (Lier, 2007 page 828).

For Christensen (1987 page 15) the term 'contingent' lumps together a variety of different factors: time on the job, location of work (i.e. homeworking) and contractual arrangements. However, contingent jobs are usually described as 'non-standard', and often do not conform to full-time, year-round work. Typically, those working in 'contingent' roles 
have "less that optimal education and skills" (Winson and Leach, 2002 page 3). Accordingly, wages are likely to be considerably lower than full-time, year-round, skilled jobs (Yalnizyan et al, 1998). Crucially, contingent labour results in far less decision-making for those involved. As Winson and Leach note, “we see people's lives become ever-more contingent upon the whims and strategies of their employers" (2002 page 11).

The variety of labour that can be defined as 'contingent' goes some way in explaining the problems employers/society face in placing/incorporating this multitude of workers. Indeed, although the Teaching Fellow does not meet all of this criteria, we find parallels with the position and situation of early-career academics (such as ourselves), who will engage in employment in a labour/capital exchange in order for their/our careers to survive. Although Teaching Fellows are a skilled group and wages are often commensurate to a pay grade appropriate for the qualifications they hold, fixed-term staff usually find themselves waged at the bottom of the scale-bracket - particularly owing to universities being able to make costsavings from 'buy-outs' for more expensive staff members. Moreover, contingent staff have differing conditions of service compared to their permanent counterparts (Hammett, 2012 page 451). These might result from measureable differences in pay and pension provision, allocation of office space and use of resources and equipment. It can also be connected to the culture of the place and whether it is exclusionary and exploitative (marginalising contract staff from "key decision-making bodies and committees" and expecting them to "shoulder extra responsibilities for which they receive no recognition" (Shelton et al, 2001 page 365)); or inclusive and supportive (taking every effort to incorporate staff into the department, through mentoring schemes, inclusion in meetings and so on (Ní Laoire and Shelton, 2002 page 99)). 
Teaching Fellows also experience differing conditions to other staff who might be labelled 'contingent'. Teaching Fellowships are strikingly different from other temporary, fixed-term, postdoctoral positions, such as a Postdoctoral Fellowship (PDF) or temporary research post. The PDF, as Hammett notes, "is viewed as a period for concerted publication supplemented by a limited amount of further research" (2012 page 447). A PDF entails the scholar embarking on their own strategy of publication (usually from their doctoral work) and independent further research. This compares to the temporary research post, where a 'postdoc' works as a Research Assistant (RA) on a project designed by an often more senior figure (although sometimes RAs collaboratively write research bids with senior staff, who act as Principal Investigators (PIs)). Importantly, in both posts "[t]eaching, supervision, and administrative duties are often discouraged, by both senior colleagues and by funding councils" (Hammett, 2012 page 447, emphasis added). In comparison, the role of the Teaching Fellow is to do just that - teach. They have a unique workload model that focuses on that 'discouraged' task of teaching and does not allocate time to writing or research (those tasks valued in university prestige, rankings and government funding).

This view of teaching as secondary to research is cemented by the very role of the Teaching Fellow. Such posts arise to cover for permanent members of a department who for one reason or another, are not teaching. Where this is due to a 'buy-out' it is particularly poignant that the 'buy-out' refers to period where the staff member is able to focus entirely on research. This is primarily due to the time consuming nature of teaching and teachingrelated activities (writing lectures, marking, feedback meetings, dissertation supervision and so on), which are detrimental to pursuing research successfully (Hammett 2012 page 447). Yet correspondingly, 'buy-outs' unintentionally act to marginalise teaching and position it as a less important, almost burdensome part of academic life (Purcell, 2007 page 130). Teaching 
is a task that can be forfeited, dropped from a staff workload, reallocated to someone temporary. So, although a number of institutions are increasing taking teaching seriously (requesting staff partake in specialist training supported by and accredited to the Higher Education Academy (HEA), and rewarding staff for teaching excellence through designated awards), it remains the case that teaching is regarded as a task less important than research.

Furthermore, the contracts of teaching staff tend to run during term time only (for nine or ten months of the year) unlike other contingent posts. This works to disadvantage the fellow: cutting them adrift during the summer months (a period of the year when academics traditionally research and write), engaging them instead in activities of job-hunting. This unique position the Teaching Fellow faces - whereby teaching time is contractually prioritised over research time - also poses implications for staff in view of the Research Excellence Framework (REF) assessment. Aware of the need for nationally and internationally outstanding publications in the 'publish or perish', research-orientated climate of academia (Hammett 2012 page 447), temporary staff must negotiate the dual demands of the institutions they work in and the aspirations of departments they hope to move to (as well as their own personal aspirations to research). Indeed, fellows must balance, in spite of skewed contracts, teaching and research, knowing the latter and REF returnable outputs will ensure their (our) best opportunity to secure more permanent positions.

Accordingly, owing to the impacts of changes in the world of work more generally, geographers have, since the 1990s (and the critical shift in the discipline), examined their own experiences and those of others working in the academy (see Hammett, 2012; Kim 2008; Ní Laoire and Shelton, 2002; Purcell, 2007; Rossi, 2007, Saltmarsh and Swirski, 2010; Shelton et al, 2001). Much of this work has focused on the neoliberal structural underpinning of the Higher Education system on the everyday lives of academics in both the UK (Castree 
and Sparke, 2000, Crang, 2007) and in global examples (Bauder, 2006, Blomley 2002, Hammett, 2012, Purcell, 2007). In short, these processes "have a number of implications for the work that geographers do" in terms of their research and teaching; and moreover, the working conditions of geographers who have positions within the academy (see Crang, 2007) and those who are trying to find a permanent place within the system (Purcell, 2007). In view of the Teaching Fellow then, whilst the example of the US has been examined, there is little discussion of the precise differences a teaching-only job might make to the experiences of those working within departments in a fixed-term capacity in a UK context. Yet the differences inherent in teaching-only job roles means they offer an alternative perspective from which to consider some of the pressing geographical questions about power, place making and mobility that are currently framing debates. Moreover, there is not one singular Teaching Fellow experience, but many. Experiences, challenges and outcomes of employment can depend on the context in which the fellow is situated. This paper therefore supports, as Purcell notes, the need to "take all elements of the non-tenure track population into account in order to adequately understand the current problem" (2007 page 124) through our differently sited accounts of the Teaching Fellow experience.

\section{A tactical approach}

Driven by critical interventions that have sought to 'expose' "the debilitating effects of ... marginalizations and oppressions", geographers (and others) are now beginning to "scrutinize the embedded and growing oppression that flows from the institutional hierarchies that structure their professional life" (Purcell, 2007 page 122). Such literature has concluded that staff who are not permanent are often outside of, marginal to, and alienated or excluded from the institutions in which they work. For example, the irregular or contingent nature of 
employment means that individuals are often less likely to experience worker solidarity (Winson and Leach, 2002 page 31).

However, although work conducted to date encouragingly raises the unequal plays of power in the contemporary academy in the UK and overseas, less is said of the ways in which staff have agency or employ methods that shape their experiences in spite of such conditions. This is perhaps why such critiques of academic labour markets (such as Purcell's, 2007) have faced scrutiny and been regarded as merely self-absorbed accounts of experience that "obfuscate ... the operations of power" (see Mercer, 2007 page 571). We do not share this view. We contend that such voices are vital in unpacking operations of power. Accordingly, the account offered here seeks to outline the creative ways in which temporary, fixed-term scholars negotiate their position, challenging structural conditions and 'strategic whims' of employers (Winson and Leach, 2002 page 11), with their own creative and empowered tactics. By focusing on 'strategies' of the academy and 'tactics' of staff, this paper seeks to take seriously the plays of power involved in the HE system. It does so without falling into a trap of either attributing 'blame', or 'playing the game' by generating positive narratives that cement the structures underpinning the neoliberal short-term academic employment market.

We focus on the tactics employed by Teaching Fellows that function as active and creative methods of intervening with the economic and structural conditions that limit their agency in the workplace. By tactics we refer to both the intentional and concerted ways in which we, as Teaching Fellows, sought to build a sense of place, security and certainty; and also to those more spontaneous moments of creativity that acted to transform our experiences ('tactics' as set out by De Certeau, 1984). Indeed, drawing in part on de Certeau's strategies and tactics - with strategies referring to the ways that spaces of everyday life are organised by those with dominant power (1997, page 34) - we understand the academy as an institution 
with "will and power" that can subsequently employ methods that control the workings of this arena to 'their' advantage (de Certeau, 1997, page 36). Such strategies seek to 'manage' those related to this 'place' (Ibid) and in the case of the academy these may include limits relating to wage brackets, contract status, pension provisions, promotion opportunities, resources and space available, and so on. Such strategies link to the wider globalised economy and to more localised, national structures that inform what the academy is able to do (neoliberal capital/labour relations, cuts to funding, and so forth). In contrast, tactics refer to the adaptive practices that are employed in opposition to and resistance against power and strategic power. Tactics are, as de Certeau notes, "weapons of the weak" - often spontaneous moments through which subjects seize opportunities to counter strategies (2007, page 37). Tactics are full of potential for those who grasp them. They may seem small or insignificant and they need not necessarily successfully overturn or defeat a certain strategic space but rather, they come to challenge and redefine it in important ways. Whilst for de Certeau these tend to be fleeting (sometimes playful) moments that twist and subvert strategies, here we also extend this to think of tactics as carefully thought-out and creatively charged moments that grant Fellows agency in the face of dominating structures that may supress them, their progression and their aspirations. Drawing on our conversations, reflections and subsequent critical analysis of our situations, it is to our own tactical experiences we now turn.

\section{Office politics}

As members of a contingent workforce, our place (physically and socially) in the departments we worked in was temporary. Yet, for both us, we had allocated pockets of space from which 
to work during our contracts. These spaces were decided on, strategically ${ }^{4}$, at a management level within our respective departments. Due to particular differences in both the context of our employment (one of us as a new member of staff, the other transitioning from $\mathrm{PhD}$ to staff in the same faculty) and our differing experiences in departmental space allocation - our offices were a source of conversation.

I was given an office - one that was usually occupied by the staff member I was covering for. I had heard stories of temporary staff who were not allocated working space in their temporary environs (see also Ní Laoire and Shelton, 2002 page 98). Yet I was to be located on a main corridor with other permanent members of staff, and able to engage with them through the proximity of our working spaces. However, it remained the case that this office was not 'officially' mine. This was confirmed when I arrived through the material items in the room that belonging to the temporarily absent, permanent member of staff. A collection of 'Annals' journals sat on the shelves, the filing cabinets were full of print-outs of articles, the desk drawers contained their stationary. Pot plants were on the window sills. Moreover, the previous occupant's name plate was still on the door. This office was 'on loan'. However, I tactically found ways to make the space my own; carving my place, in this, someone else's space (Cresswell 2006 page 4).

Firstly I enquired about a new name plate. As Cresswell notes, a powerful way in which we begin to establish a 'sense of place' is through 'naming' (2004 page 10). Indeed, immediately this enabled me to take 'root'. As Purcell argues, an allocation of space is a signal of belonging. For him (as for me) his stake to space disappeared at the end of the teaching contract (2007 page 135). Nevertheless, the case remains, for a duration, having

\footnotetext{
${ }^{4}$ Here 'strategic' refers not to a manipulative power by respective departments to instil labour hierarchy, but to decisions by management in relation to available office space.
} 
space is a key ingredient in forging a sense of belonging. Materiality was also a way in which I began to feel 'in place'.

As Cresswell explains regarding his office, personal items make the space his own: "[t]he walls are decorated with posters, postcards, maps ... Many of the postcards say things I think relate to me in some way ... These are interspersed with pictures of my family and copies of my book covers" (2006 page 32). The notice boards in 'my' room were empty, along with a couple of the shelves. In spite of my temporary nature, I chose to fill these spaces (even though I knew before long I'd have to remove the items). Like Cresswell, the material things on display were personal to me - my books (reflecting my intellectual sensitivities), the London place name pen pot (a reminder of home), and a Las Vegas snow globe (a testament to some earlier research on tourist souvenirs). In a matter of hours the office really began to look like mine. Through simply surrounding ourselves with personal possessions, we can turn an empty and unfamiliar space into somewhere meaningful and 'known'.

These acts of place-making were tactical in view of my onward career trajectory. I found through making the space my place, I was able to create a comfortable working environment that was conducive to work. This enabled me to complete a variety of tasks from lecture preparation to the articles that would help to secure future employment. Shaping the office as my own also enabled me to feel more secure in my professional capacity as a faculty member. Conversely, Jen's experience was somewhat different:

The Head of Department popped around the door of the student office I had occupied for the last 18 months, sitting down in the single guest chair. Earlier that day I had interviewed for the Teaching Fellow role. I was now being offered the job. The next week I walked back into the department (a place that had been my academic home for over seven 
years) to begin a new phase of my academic career, a six-month Teaching Fellowship alongside the final stages of my PhD - a strange hybrid between staff and student. I was to occupy the same office I had as a student, yet my professional place was quite different. I faced a tension whereby I was reminded of my temporary nature through my office allocation. It was needless to move me to another room when my contract was so short and the new incoming member of staff I was covering for would no doubt arrive before my term had ended.

For Jen, her position as an existing figure within the department she now worked for shaped her allocation of space. It was easier to remain where she was, but this strategic institutional move also worked to make her professional position uneasy. Indeed, from feeling 'delighted to be a 'proper' staff member', Jen soon 'felt perturbed after a couple of weeks'. As she explained:

Nothing had really changed. I expected that my stasis - the security offered by seven years' experience in one place - would have helped my feel more rooted in my professional capacity. Instead, I found it strange. For example, I had to explain to the tutorial students whom I was continuing to teach, that I was now a staff member not a postgraduate tutor. Conversely, I found that some staff members still referred to me as a PhD student and I found this disconcerting. Furthermore, the material space afforded to me, in continuing in the same office, geographically disconnected from other staff members, seemed to reinforce this position further. The stable, rooted experience that I had relied upon to inspire confidence in my professional capabilities as a member of teaching staff had instead contributed to my being in limbo, in a state of flux.

For Jen, making a place for herself in the face of material, institutional constraints was challenging. She did attempt to make the office 'more professional' on the advent of her 
employment by removing more personal items from the wall and tidying the space for oneon-one meetings with dissertation students. Yet there was little scope for her to occupy a (more permanent) place in the academy. Tactically, however, she was able to find an alternative way to negotiate these constraints through making (and taking) virtual space in the department on the university web pages. Jen had an existing web presence on the student tab of the departmental pages. This would have remained the case had she not ask to be moved, virtually, to the staff tab. She re-wrote her web page to mirror those of academic staff, listing teaching responsibilities, administrative duties and publications. For the students she taught, she now had a presence (virtually, if not geographically) that placed her alongside her colleagues and better asserted her position as staff. As such, for anyone visiting the website, there was no signal that she was only a short-term fixture.

In these examples, we have illustrated how, through creative practices, we were able to assert a presence that offered some stability and rootedness to our positions, from which to gain confidence in our abilities. We argue that place-making, actually and virtually, is important to the Fellow's esteem. In early-career posts (when scholars are still gaining confidence) it matters that they are enfolded into departments, and occupying space is one way that makes this possible. Here we have shown how we were able to tactically 'take place' - yet this also acts as a call for departments, at a strategic level, to 'make place' for staff, however temporary.

\section{Facial recognition}

Jen's web page worked to make her visibly present amongst students and colleagues. However, as Jen and I discussed, presence in a corporeal sense was also an important tactic in 
securing our feelings of belonging. It was apparent through our conversations that presence established through daily practices and routines - enabled us to forge a sense of place. As Tuan notes, "[t]he functional pattern of our lives is capable of establishing a sense of place" (1999 page 452). 'Functional' is the key word here. We develop a sense of place through daily practices that are quite mundane and habitual. Seamon (1979) contends that through particular body-ballets (the habitual movements of bodies) and time-space routines (those habitual body movements occurring repeatedly over time), we create familiarity and build a sense of 'being' in the world. As such, "recognizable and regular patterns of practice emerge" which give shape to our experiences, helping us feel 'in place' (Cresswell, 2006 page 33). As such, "[i]t is through participating in ... daily performances that we get to know a place and feel part of it" (Cresswell, 2004 page 34). It was through the routine of being in the departments we worked in frequently, that place-ballets of familiarity formed (Seamon, 1979). Indeed, this presence saw us both develop regular practices. There were the frequent visits to the departmental office to discuss marking deadlines and other teaching-related administration (necessary because of our roles as teaching-intensive members of staff). Then there was the lecturing, week in, week out. Purcell states that it is through teaching that temporary staff can find a 'place' (2007 page 135). Students, unaware of the contractual status of staff, “accept you readily as a full faculty member" (ibid, 2007 page 135). Subsequently, staff begin to practice and perform the role of a more permanent staff member in spite of their actual impermanence. Given the higher-than-average portion of time that we both spent in the lecture theatre, the seminar room, or the office engaging with the student population, it is little wonder our 'place' became more established and our confidence grew in the face of contractual positions. A fixed-term contract, as Purcell (2007) notes, can evoke feelings of inferiority, which are built into a hierarchical system that assumes non-tenured 
staff are somehow less able and less deserving - in other words, 'not as good' academics - as their permanent counterparts.

As discussed earlier, Teaching Fellowships are often regarded to be at the bottom of the academic ladder. However, our posts showed that teaching positions should not been seen as separate from, or inferior to research posts. Arguably teaching staff are “indispensable" (Purcell, 2007 page 122) because they (we) make a central contribution to the functioning of academic departments. Whilst Fellows may not have a direct role in research production within a university, they do have a central place in the dissemination of geographical knowledge. Moreover, with the changing fee climate in UK institutions, the role of teaching is arguably heightened as emphasis on undergraduate and postgraduate experience (and satisfaction) takes a more central place in the functioning of academic departments. Departments are now encouraged to invest in a greater number of contact hours between staff and students and to develop more innovative approaches to learning in order to compete against other institutions and capture potential students. The role of teaching-only staff cannot be underestimated or undervalued in contributing to this agenda.

The presence of Teaching Fellows, like us, provides a flexible labour provision that allows the research activities of the department to excel and accelerate given the relief such Fellows provide to research staff (Shelton and Ní Laoire, 2002 page 99). Certainly, as we have already noted, when large grants are obtained it is telling that they often involve teaching 'buy-outs'. However, these 'buy-outs' were ways in which, as temporary staff, we were able to creatively and tactically 'buy-in' to the department and establish a sense of (temporary) security. Of course being present in the department could be seen as an essential part of the job, not a tactic for negotiating contingent positions. However, whilst Fellows may necessarily have to be in the department to complete duties required, they can assert their 
presence in other ways that benefit their future career trajectories. Indeed, although not usually required, Fellows can insist on sitting on exam boards and committees, attending meetings, and participating in open days, giving them vital experience in tasks relevant to developing their administrative skills and understanding of the HE system. I reflected over coffee with Jen how a 'buy-out' often makes a permanent staff member less visible: they are absent from the usual activities of staff as they are no longer required to attend certain meetings, teach, supervise students and so on, through the duration of their funding. For Jen, taking up these tasks was a way of embedding herself into the department and gaining an insight into the academy. This enabled her to identify herself as a potential candidate for a subsequent post, either at the same or another institution. As Jen told me,

When emails came through to me regarding departmental meetings, most invitations specified that, for example, degree scheme co-ordinators, module conveners or moderators would be expected, with "all other staff welcome to attend". This left me unsure of my obligations. My closer colleagues informed me that there was no reason for me to go unless I was identified in one of those named roles (which I never was), but that it was bound to be a useful experience in finding out more about the inner-workings of a HE institution. Certainly, in attending such meetings I did find this to be the case. I soon became aware of details of a whole host of processes from module accreditation, to special circumstances and awarding of degree classes. If another post became available at the end of my contract, I wanted to appear knowledgeable about the department, if not, then I knew these experiences would have wider applications.

Jen's account illustrated similarities with my own experiences. Such practices were a tactical way of positioning ourselves advantageously - in view of opportunities both within the department we worked in, and in any future institutions. This is not to say that temporary 
staff must go 'above and beyond' to secure employment, but that we have the agency to tactically shape our career trajectories through choices we make in the workplace. Aside from our attempts to involve ourselves in formal departmental activities, we also found ourselves reflecting on the informal practices we developed in order to further embed ourselves in the workplace.

\section{Coffee and collaboration}

This paper, in revised form, began with a coffee. On the one hand, coffee breaks for both Jen and I were a routine practice made possible by the labour/capital exchange (unlike when we were $\mathrm{PhD}$ students, we could now afford to frequent the university coffee shop like our permanent colleagues). Yet on reflection, it was during these coffee breaks that Jen and I began to tactically negotiate our positions in the most effective ways: through our camaraderie and collaboration.

As Purcell notes, temporary staff may be undervalued by the structural system they work in and the broader academic view that disvalues their activities (2007 page 135). It can also result from a feeling of isolation (Purcell, 2007 page 135). Indeed, Hammett notes that research 'postdocs' can remain particularly peripheral because they are unable to participate in some of the more "mundane, administrative aspects of academic life", which are in fact pivotal to the running of departments and feeling embedded within places (2012 page 453). In comparison, the specific role of Teaching Fellow, as we have noted, engages readily with such tasks, often interacting with support staff, fellow lecturing colleagues and students alike. In particular, Jen and I found our friendship with one another to be a tactic for making a place for ourselves in a situation of flux and dislocation. Our shared experiences of working on the 
academic coalface in temporary positions enabled us to build solidarity and stability amidst change and uncertainty. From talking over coffee about our experiences (and the differences and similarities between them), sharing lecture materials and discussing pastoral issues, we were tactically able to challenge these conditions. We countered such circumstances by forming a friendship that would endure beyond temporary conditions, which we could also draw upon to develop our sense of place in the academy.

I was in my second post when I met Jen. She was starting her first academic position. Having already experienced a temporary teaching post, and being new to the department Jen was embedded in already, I offered her a soundboard - someone who understood the nature of contingent conditions - but also, a friendship not predicated on any previous knowledge of her as a student or postgraduate tutor. As Jen herself stated,

Kim was a new face to the department. The fact that she had moved from another institution meant that she encountered me as any other new colleague might. She hadn't seen me as an 18-year-old undergraduate or advised me in a pastoral capacity as a student. Instead, for her, I was a peer with my own useful knowledge that I could share with her. That gave me a sense of confidence in my own abilities. It was Kim's mobility then, which helped me to feel more rooted in the department I had already spent so much time in.

It was my own mobility as a member of the contingent workforce that made possible a sense of reassurance and stability for someone else. And this process worked both ways. Jen, embedded within the department I had joined, helped me to develop a sense of place to counter the feelings of upheaval and change that came with my move west. For example, her experience within the department as a student, postgraduate and staff member, meant she had inside knowledge, contacts and experience that enabled me to tactically 'take root' quickly (for example, she knew which porters to contact to acquire help moving and the technical 
staff to see to gain help with computing mishaps). Moreover, the routineness of those coffees provided a sense of consistency to my days. Her friendship made me feel settled. On the one hand then, as we noted at the start, our shared experiences 'bonded us' and offered us a security through friendship (see Bunnell et al, 2012). Yet it also enabled us to gain experience and knowledge from one another, tactically, to put us in the best possible places for taking root and moving forward.

Indeed, it wasn't just a camaraderie that helped to negotiate our position. We used our friendship as a basis for collaboration too. We knew that academics in short, fixed-term posts or on probation in early-career positions face particular challenges for their longer-term career progression. Temporary staff, research and teaching, already suffer considerable disadvantages in terms of securing permanent posts because they do not have a stable base from which to develop their ideas, research proposals, papers, and teaching portfolio. They "simply ... do not know where they will be in a year's time" (Shelton et al, 2001 page 436). This mobility-induced uncertainty is compounded for the Teaching Fellow because they are not allocated research or writing time. As Hammett reflects, drawing on his own postdoctoral experiences, "while teaching experience was beneficial, my publication profile and track record in securing funding were vital to my career aspirations" (2012 page 447). Discussing our own career goals, Jen and I tactically negotiated the heavy teaching loads and limitations this posed to writing and research through collaborating on ideas that led to this paper. More than this, we found collaboration a way to share a workload when we were time-pressured. And it wasn't just this paper. We found commonalities in other elements of our work too. Whilst we appreciate this scenario might not be replicated for all Teaching Fellows, it demonstrates how Fellows might creatively collaborate with colleagues, both temporary and 
permanent, to further their research and publishing profiles, resisting the contractual limitations placed on them.

\section{Beginnings and endings}

As we draw towards conclusions, it is important that we reflect on the ways in which our experiences have been shaped - attending to our positionality and situating our knowledge of the academic labour market (Mercer, 2007; Rose, 1997). There is no doubt an expression in both of our accounts of our good fortune of securing academic appointments at early stages of our careers. This exhibits similarities to contingent labour practices, whereby employment is described as fortuitous (Winson and Leach, 2002 page 5). However, like many of our academic counterparts (both temporary and permanent), our observations here have been shaped by the fact we genuinely enjoy teaching. Rather than regarding it as a burdensome part of academic life, the challenge of communicating ideas to enthuse students and encourage them to think critically about the world around them is something we both regard as an exciting task.

Our reflections are also a consequence of our place in the career ladder. As Ní Laoire and Shelton note in their survey of experiences of fixed-term staff, those who have been on the fixed-term circuit for shorter periods have "lower levels of expectation" compared to those who have 'played the game' longer and have more "frustrated expectations" as they compare their working lives to their permanent counterparts (2002 page 95). Moreover, it is those on their first contract who typically tend to see such posts as "advantageous" (ibid, 2002 page 94). It may be the case then that these autobiographical accounts are clouded by the short lapse between being a student and a staff member and the novelty of occupying this position. Furthermore, our experiences have certainly been influenced by the institutions we 
worked in and most significantly, the people we worked with. Ní Laoire and Shelton note that "levels of satisfaction may reflect institutional practice" (2002 page 96). Both of us had relatively favourable experiences, yet we have been able to show how tactical practices can enable security amidst contractual and structural uncertainty that comes with contingent positions.

In this paper we have reflected upon two experiences of fixed-term, temporary, teaching contracts held at different UK Higher Education institutions between 2011 and 2013, which eventually led to us working in the same department. For one of us, the start of a new position involved immediate relocation; a move South to North, to a new city, flat and workplace. For the other, the beginning was hazier - the significant move was from the position of student to the hybrid role of student/staff member. There was no change in location to a new town, house or office. Yet these two posts also had striking similarities. We were both fixed-term. We were both temporary. We both had contracts that terminated at the end of the teaching term when our services were no longer required. There were high teaching loads to contend with, alongside the necessity to publish at the same time in spite of no allocated time for writing and research activities built into our contracts. One of us also had a $\mathrm{PhD}$ to finish. Both contracts were underscored by a broader academic climate that placed teaching below research as a valued task.

However, we found when we met, in spite of the differing institutions we worked in as Teaching Fellows and the varying situations that led to and underpinned our positions, we both employed tactics of negotiating the contingent nature of our employment in response to structural and institutional conditions that often leave Fellows with little control over their career trajectories. In this paper, we have reflected on our experiences to consider the often marginalised voice of teaching-only staff in the UK academy. We have done so in order to critically consider our own working environments and our attempts to negotiate the neoliberal 
contingent labour market. Accordingly, we demonstrate how Teaching Fellows may achieve productive outcomes in the face of challenging employment conditions. It is our hope that by exemplifying our own experiences, other Teaching Fellows may likewise identify spaces where creative and tactical negotiation may take place in order to find their (more permanent) place within the academy.

\section{Acknowledgements}

We owe our thanks to the guidance offered by the reviewers in helping us develop this paper. Importantly, we would like to thank our colleagues in the departments where we held our temporary contracts - the University of Sheffield and Aberystwyth University - for their support during our employment.

\section{References}

Amin A, 1994, Post-Fordism: A Reader (Blackwell, Oxford)

Baulder H, 2006, “The segementation of academic labour: a Canadian example". $A C M E \mathbf{4}(2)$ 228-239

Blomley N, 2002, “The rules” Geoforum 33(2) 149-151 
Bunnell T, Yea S, Peake L, Skelton T, Smith M, 2012, "Geographies of friendships" Progress in Human Geography 36(4) 490-507

Castree N, Sparke M, 2000, "Professional geography and the corporatization of the university: experiences, evaluations, and engagements" Antipode 32(3) 222-229

Christensen K, 1987, “Women and contingent work” Social Policy 17(4) 15-18

Crang M, 2007, "Commentary: Flexible and fixed times working in the academy" Environment and Planning A 39 509-514

Cresswell T, 2004, Place: A Short Introduction (Blackwell Publishing, Oxford)

Cresswell T, 2006, "Individual Place" in The Companion Encyclopaedia to Geography Eds. I Douglas, R Huggart, C Perkins (Routledge, London) 31-41

De Certeau M, 1988, The Practice of Everyday Life (University of California Press: London)

Denzin N K, 1989, Interpretive Biography. (SAGE: Newbury Park, CA) 
Dicken P, 2003, Global Shift: Reshaping the Global Economic Map in the 21st Century (Sage, New York)

Dowling R, 2008, “Geographies of identity: labouring in the 'neoliberal' university Progress in Human Geography 32(6) 812-820

Ellis C, Bochner A P, (2000), “Autoethnography, personal narrative, reflexivity: researcher as subject" in The Handbook of Qualitative Research Eds. N K Denzin, Y Lincoln (SAGE: Thousand Oaks, CA) 733-768

Hammett D, 2012, "Tales from the road: reflections on power and disciplining within the academy" Environment and Planning A 44(2) 445-457

Heyman R, 2007, “'Who's going to man the factories and be the sexual slaves if we all get PhDs?' Democratizing knowledge production, Pedagogy, and the Detroit geographical expedition and institute" Antipode 39(1) 99-120

Kim T, 2008, “Transnational academic mobility in a global knowledge economy: comparative and historical motifs" in Geographies of Knowledge, Geometries of Power: Framing the Future of Higher Education Eds. D Espstein D, R Boden, R Deem, F Rizvi, S Wright (Routledge, New York and London) 319-337 
Lier D, 2007, "Places of work, scales or organising: a review of labour geography" Geography Compass 1(4) 814-833

Mercer D, 2007, "The Dangers of Autobiographical Research: A Response to Purcell" Antipode 39(4) 571-578

Ní Laoire C, Shelton N, 2002, “CContracted out': some implications of the casualization of academic labour in geography” Area 35(1) 92-100

Purcell M, 2007, “'Skilled cheap and desperate': non-tenure-track faculty and the delusion of meritocracy" Antipode 39 121-143

Rose G, 1997, "Situating knowledges: positionality, reflexivities and other tactics" Progress in Human Geography 21(3) 305-320

Rossi U, 2007, "Being here and there: In-betweeness, double absence, and the making of a multilayered academic citizenship" Area 40(3) 401-406 
Saltmarsh S, Swirski T, 2010, “'Pawns and prawns': international academics' observations on their transition to working in an Australian university" Journal of High Education Policy and Management 32(3) 291-301

Seamon D, 1979, A Geography of the Lifeworld. [online] www.arch.ksuedu/seamon/lifeworld_chaps Accessed 12 July 2013.

Shelton N, Ni Laorie C, Fielding S, Harvey D, Pelling M, Duke-Williams O, 2001, "Working at the coalface: contract staff, academic initiation and the RAE" Area 33(4) 284-293

Tuan Y F, 1999, "Space and Place: Humanistic Perspective" in Human Geography: An Essential Anthology Eds. J Agnew, D Livingstone, A Rogers A (Blackwell Oxford, Cambridge) 444-457

Winson A, Leach B, 2002, Contingent Work, Disrupted Lives: Labour and Community in the New Rural Economy (Buffalo, University of Toronto Press)

Yalnizyan A, Ide R, Cordell A J, 1994, Shifting Time: Social Policy and the Future of Work (Toronto, Between the Lines) 